\title{
BONITATION ANALYSIS OF TURF ON CITY STADIUM IN WROCLAW IN THE SEASON OF EURO 2012
}

\author{
Karol Wolski' ${ }^{1}$ Grzegorz Janik2 ${ }^{2}$ Jarosław Czarnecki ${ }^{3}$ Justyna Ziarko', Marta Talar-Krasa', \\ Amadeusz Walczak², Magdalena Biernacik', Małgorzata Dawid ${ }^{2}$
}

\footnotetext{
Department of Agroecosystems and Green Areas Management, Wrocław University of Environmental and Life Sciences, pl. Grunwaldzki 24A, 50-363 Wrocław, Poland, e-mail: karol.wolski@up.wroc.pl, marta.talarkrasa@up.wroc.pl, justyna.ziarko@up.wroc.pl, magdalena.biernacik@up.wroc.pl

2 Institute of Environmental Protection and Development, Wrocław University of Environmental and Life Sciences, pl. Grunwaldzki 24, 50-363 Wrocław, Poland, e-mail: grzegorz.janik@up.wroc.pl, amadeusz. walczak@up.wroc.pl, malgorzata.dawid@up.wroc.pl

3 Institute of Agricultural Engineering, Wrocław University of Environmental and Life Sciences, ul. Chełmońskiego 37/41, 51-630 Wrocław, Poland, e-mail: jaroslaw.czarnecki@up.wroc.pl
}

Received: 2016.06.06 Accepted: 2016.08.08 Published: 2016.09 .20

\begin{abstract}
In 2012-2013, a study was conducted, consisting in a bonitation analysis of turf on the City Stadium which is located in the north-west part of Wroclaw and was a sport arena of the European Championships Euro 2012. The experiment was made with the complete randomisation method for 2 factors, on 5 dates in the growing season. On the turf of the pitch 12 points were selected, and at each of them an evaluation of utility features was performed, in 4 replications, on surface area of $1 \mathrm{~m}^{2}$. Based on the observation of the condition of the turf, during subsequent analyses it was found how the selection of the mixture of grasses, intensity of use and pratotechnic treatments affect the bonitation quality of sport turfgrass. The results are shown in relation to the whole object, separating each of the features under analysis.
\end{abstract}

Keywords: sports turf, bonitation analysis, general aspect, colour, sodding, susceptibility to disease, winter survival

\section{INTRODUCTION}

Interest in football dates back to Ancient Egypt, Rome or Greece. Initially, there were no rules and the games were played on natural green areas. The Football Federation formed in 1863 in Britain developed the rules of this game. To this day, matches played by football teams on the biggest sport arenas, where the sports turfgrass is of the highest quality, are very popular and viewed around the world [Wolski et al. 2006].

High standard of the turf surfaces is very important for the efficiency and safety of the players. Turf subjected to continuous mechanical destruction must survive excessive use during the training and matches [Macolino et al. 2004a, Macolino et al. 2004b]. In order to maintain high quality of the turf, which is subject to exploitation, both visual and functional, the turf should be well rooted and permanent, and the lawn should be dense and uniform colour [Turgeon 2008]. Attention should also be focused on the resilience, speed, stiffness and rebound the turf. These parameters define the optimal conditions for turning, flipping and running the ball, which is important not only for the players, but often also for the very match results [Wolski et al. 2006].

The key to obtaining sports turfgrass meeting the visual and functional aspects is the composition of a special mixture of turf grasses. In the climate conditions of Lower Silesia, the best species are perennial ryegrass and Kentucky bluegrass which are resistant to heavy trampling and low mowing [Pląskowska et al. 2006]. Lolium 
perenne L. is low loose clump grass with a lot of rich green and glossy leaves. It is characterised by rapid growth in the spring, giving a nice lawn throughout the growing season. Perennial ryegrass is resistant to trampling and it has regenerative properties after mechanical damage, so this species is considered to be the most durable and the best for intensively exploited areas. Poa pratensis $\mathrm{L}$. is also a grass that is resistant to low mowing and trampling, with loose clump structure and underground stolons. Due to its large amount of short and flattened shoots, this species is responsible for the formation of uniform and strong turf. The best decorative value is noticeable in the summer, when the turf colour is the most juicy and expressive [Mynett et al. 2010, Turgeon 2008, Wolski et al. 2006]. At the City Stadium in Wroclaw, ready-to-lay rolled turf was applied, composed of $50 \%$ of Lolium perenne (varieties Disco $-20 \%$, Vienna $-20 \%$, Fragment $-10 \%$ ) and $50 \%$ of Poa pratensis (varieties Cocktail - 20\%, Julia $-20 \%$, Cynthia $-10 \%$ ), varieties registered in the Common Catalogue of Varieties of Agricultural Plant [European Commission 2012].

Selection of the right mixture of grasses does not in itself guarantee the achievement and maintenance of high quality sports turfgrass. Achieving this objective requires proper preparation of the substrate (including drainage), and knowledge of pratotechnics. In the construction of modern sports pitches, such as e.g. the City Stadium, the substrate is built with a majority of sand which, together with the soil, forms granular support for the lawn layer. It is very important, because it collects a part of infiltrating surface waters and drains excess water to the drainage system. After compaction and homogenising, the vegetation layer should have water permeability at a level greater than $5 \mathrm{~cm} / \mathrm{h}$, compaction of $0.75-0.95$ $\mathrm{MPa}$, and clay content of $8-12 \%$ and organic carbon content ( $\mathrm{C}$ org.) at $1-3 \%$. The reaction of substrate for sports grounds should be $\mathrm{pH}$ 5.57.0. Ready-made rolls of turf, with thickness not exceeding 20-25 mm, are laid on the moistened and loosened layer of the substrate. At the same time, it is pressed with roller and irrigated with water at a rate of $10-151 / \mathrm{m}^{2}$. Given the regional differences in climate, favourable conditions for grass rooting are in periods from the beginning of April to mid-June, and from mid-August to the end of September [Deutsche Norm, Skirde 2008]. Sports turfgrass care is not just about mowing, watering or fertilising. The emerald shade of turf is ensured by correctly performed series of treatments which also include aeration, scarification, sand sprinkling, rolling and disease control. All of these treatments should be carried out accurately and regularly to reduce the costs associated with the replacement of turf, and to achieve a high overall aspect of turf [Loch 2013, Wysocki 2002].

The objective of this study was to evaluate the utility value of the football turf in the City Stadium in Wroclaw during the growing season of 2012-2013 (before, during and after the European Championships - Euro 2012). The analysis was made based on the methodology the Centre of Research on Cultivated Plant Varieties for the estimation of the economic value of varieties of turf grasses. The results were elaborated for specific characteristics, taking into account the place and date of observation, and on their basis conclusions were formulated, defining the effect that the choice of a mixture of grasses, the intensity of care treatments and method to use have on the overall aspect of football turf.

\section{MATERIALS AND METHODS}

The bonitation analysis of turf was performed on the City Stadium in Wroclaw, located in the Pilczyce district, at Śląska Avenue. It is situated in the vicinity of Motorway Ring of the city of Wrocław, providing easy access to the sports object from every direction. The utility value analysis of the football turf was carried out on 5 dates during the growing season in 2012 and 2013. Each time the analysis was performed according to the same pattern of movement on the pitch, isolating 12 objects ( 6 per each half) located between the central line of the pitch and the 16-metre line. In each of the 12 points four replications were made within $1 \mathrm{~m}^{2}$ from the target point, for 2 experimental factors (place and date of observation). The study was performed with the method of complete randomisation.

The first factor (A) was the date of observation. The 5 dates of observation were the following: $\mathrm{A} 1$ - 20.04.2012 (spring), A2 - 31.05.2012 (spring), A3 - 26.06.2012 (summer), A4 - 22.10.2012 (autumn), A5 - 26.04.2013 (only spring - winter survival). The bonitation analysis was performed only if the substrate humidity conditions were comparable ( $28-32 \%)$. The second factor was places of observation on the football pitch, numbered from 1 to 12, presented in Figure 1. 


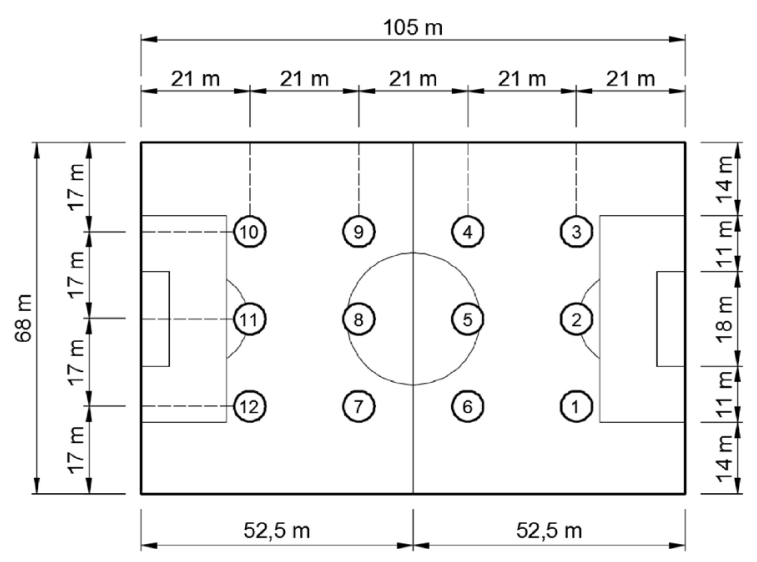

Fig. 1. The observation points.

The bonitation analysis, performed on the basis of the COBORU method, included the determination of the general aspect (Ao), sodding $(\mathrm{S})$, colour $(\mathrm{C})$, susceptibility to disease $(\mathrm{Sd})$ and winter survival (W). The result of the observations were presented on a 9 point scale, where the figure 9 is the highest note and the figure 1 is the lowest [Domański 1992].

Additionally, for better analysis of the results obtained, maps of spatial distribution of the above parameters were created. These distributions were created for illustrative purposes. Surfer ${ }^{\circledR} 13$ program was used to visualise the results. This software uses a number of geostatistical interpolation methods called kriging. The study presents the general aspect, colour and sodding of the turf on three selected dates: immediately before, during and after the European Championships.

\section{RESULTS}

\section{Chemical properties of the substrate and the content of macro- and micronutrients in the vegetation layer on the City Stadium in Wroclaw}

Based on the analysis of chemical properties of the substrate made at the Centre for Environmental Quality (Accreditation PCB AB 1293), belonging to the Institute of Soil Science and Environmental Protection, Wroclaw University of Environmental and Life Sciences, it was concluded that the $\mathrm{pH}$ values (measured in $\mathrm{KCl}$ and $\mathrm{H}_{2} \mathrm{O}$ ) at the selected points fall within the limits permitted for the construction of substrates of soccer pitches (5.5-7.0). Correctly constructed soil layer largely affects the normal growth and rooting of the grass. This is a fundamental parameter, as the reaction of the vegetation layer of the substrate affects the uptake of minerals and, consequently, the growth and rooting of grasses, as well as the potential appearance of undesirable plants species.

In the examined soil samples the total content of organic carbon fluctuates in the range from $1.45 \%$ to $1.6 \%$ (Table 1 ). The average OC content at the chosen points was determined on the level of $1.52 \%$. It means that its share is slightly lower than the optimum according to the standard DIN $18035-4\left(2 \%\right.$ of $\left.\mathrm{C}_{\text {org }}\right)$. As organic carbon is the main component of humus, its correct level is of great significance. Humus is regarded as an important indicator of soil fertility, affecting soil physical, chemical and biological properties to a larger extent than the remaining elements of soil [Drozd et al. 2002].

The fertilisation requirements for specific macro- and micronutrients were determined on the basis of the limit values for agricultural crops, and the nutrient content of the vegetation layer was defined in five samples and presented in a form of two reports on the average values from the tests.

Based on the information provided in Table 1, it was concluded that the content of the individual elements were at a low level $(\mathrm{K})$, optimal $(\mathrm{Cu}$, $\mathrm{Mn}, \mathrm{Zn})$, medium $(\mathrm{P})$ and very high $(\mathrm{Mg}, \mathrm{Fe})$. Attention is due to elements that are in deficit and in excess, because both extremes are not favourable for the growth of turf. In the case of total absence of an element, supplemental fertilisation is rec-

Table 1. Chemical properties, density and moisture of the current vegetation layer.

\begin{tabular}{|l|c|c|}
\hline \multicolumn{1}{|c|}{ Specification } & Average & Range \\
\hline Corg. [\%] & 1.52 & $1.45-1.60$ \\
\hline $\mathrm{pH}$ in $\mathrm{KCl}$ & 5.43 & $5.20-5.60$ \\
\hline $\mathrm{pH}$ in $\mathrm{H}_{2} \mathrm{O}$ & 6.30 & $6.10-6.50$ \\
\hline $\mathrm{P}[\mathrm{mg} / 100 \mathrm{~g}$ of the soil] & 14.8 & $4.3-33.7$ \\
\hline $\mathrm{K}[\mathrm{mg} / 100 \mathrm{~g}$ of the soil] & 8.8 & $2.7-13.7$ \\
\hline $\mathrm{Mg}[\mathrm{mg} / 100 \mathrm{~g}$ of the soil] & 7.8 & $3.6-11.3$ \\
\hline $\mathrm{Cu}[\mathrm{mg} / \mathrm{kg}$ of the soil] & 10.1 & $2.1-21.1$ \\
\hline Fe [mg/kg of the soil] & 7488 & $5080-12020$ \\
\hline $\mathrm{Mn}[\mathrm{mg} / \mathrm{kg}$ of the soil] & 171 & $103-301$ \\
\hline $\mathrm{Zn}[\mathrm{mg} / \mathrm{kg}$ of the soil] & 52.6 & $9.5-101.1$ \\
\hline Compactness [MPa] & 0.84 & $0.75-0.92$ \\
\hline Volumetric moisture [\%] & 28.9 & $28.1-31.2$ \\
\hline
\end{tabular}


ommended, and in the case of an excess, the supply of such an element should be limited.

The contents of $\mathrm{Cu}$ and $\mathrm{Zn}$ in examined soil samples fell within permissible values for the soil of urbanised areas in accordance with standards of soil and earth quality [Regulation of the Minister of the Environment of $9^{\text {th }}$ September 2002].

Iron enhances the resistance of grasses to pests and diseases, and also helps plants to survive the winter. Grass fed with the appropriate form of iron gaining beautiful and lively colour. In the examined samples the average content of Fe was found at the level of $7488 \mathrm{mg} / \mathrm{kg}$ of soil, which indicates considerable contents of this element in the soil.

Summing up, one should state that controlling the content of components permits the avoidance of conditions unfavourable for the growth of turf and is one of the stages in the process of achieving the emerald colour of grass.

\section{Assessment of the value of overall aspect}

During the estimation of the overall aspect (Ao), in 2012, on various dates (spring, summer, autumn), it was found that the turf at the City Stadium in Wroclaw was more or less diversified in terms of aesthetics (Table 2).

The largest differences were observed during the analysis of the overall aspect at point No. 5 (A3), located in the SE part of the pitch, near the 16-metre line, that were caused by the European Championships Euro 2012 held in June and the overexploitation of the turf. The least diverse values were recorded during the study in the second spring term - 31. 05. 2012 (A2).

This was due to the final preparation of the turf for the European football games and to the intensive care treatments carried out. Analyses No. 1 (A1) and 4 (A4) presented similar results in terms of variation of turf appearance, which shows that condition of the turf at the beginning and at the end of the growing season was similar.

However, all the analyses confirmed that turf at points $7-12$, located on the left half on the pitch, was in a much better condition than at points 1-6, located on the opposite side. Over the entire study period the left side of the field (points 10-12) was characterised by better overall aspect value than the right side of the field (Fig. 2). This effect was due to less intensive exploitation during training and better lighting of the turf in the north part of the pitch compared to the south side.

\section{Assessment of sodding value}

In the estimation of sodding (S) in 2012, on various dates (spring, summer, autumn), it was found that substrate coverage with leave blades was varied (Table 3 ).

Similarly, as in the earlier study, it was noted that both the preparation and the intensive exploitation of the turf during the Euro 2012 had a material impact on the sodding of the football pitch. The reported values for sodding in the analysis of 26.06.2012 (A3) fell within the broadest range,

Table 2. Assessment of the general aspect (Ao) in relation to the time and place of observation, $\mathrm{a}_{1}-\mathrm{f}_{4}-$ homogeneous groups.

\begin{tabular}{|c|c|c|c|c|c|}
\hline Description & $\begin{array}{c}\mathrm{A} 1 \\
(20 \mathrm{IV} \mathrm{2012})\end{array}$ & $\begin{array}{c}\mathrm{A} 2 \\
(31 \mathrm{~V} \mathrm{2012)}\end{array}$ & $\begin{array}{c}\mathrm{A} 3 \\
(26 \mathrm{VI} 2012)\end{array}$ & $\begin{array}{c}\mathrm{A} 4 \\
(22 \times 2012)\end{array}$ & Average Ao \\
\hline 1 & $6.50 \mathrm{~d}_{1}$ & $6.76 \mathrm{c}_{2}$ & $6.76 \mathrm{~d}_{3}$ & $6.45 \mathrm{e}_{4}$ & $6.60 \mathrm{e}$ \\
\hline 2 & $5.86 \mathrm{e}_{1}$ & $6.05 \mathrm{~d}_{2}$ & $6.60 \mathrm{e}_{3}$ & $5.86 \mathrm{f}_{4}$ & $6.10 \mathrm{f}$ \\
\hline 3 & $8.01 \mathrm{a}_{1}$ & $7.78 \mathrm{a}_{2}$ & $7.24 \mathrm{c}_{3}$ & $7.78 \mathrm{~b}_{4}$ & $7.67 \mathrm{~b}$ \\
\hline 4 & $7.45 \mathrm{c}_{1}$ & $7.73 \mathrm{a}_{2}$ & $7.73 \mathrm{~b}_{3}$ & $7.51 \mathrm{~b}_{4}$ & $7.62 \mathrm{~b}$ \\
\hline 5 & $6.05 \mathrm{e}_{1}$ & $6.25 \mathrm{~d}_{2}$ & $5.66 \mathrm{f}_{3}$ & $6.92 \mathrm{~d}_{4}$ & $6.20 \mathrm{f}$ \\
\hline 6 & $6.40 \mathrm{~d}_{1}$ & $6.92 \mathrm{c}_{2}$ & $6.97 \mathrm{~d}_{3}$ & $7.29 \mathrm{c}_{4}$ & $6.86 \mathrm{~d}$ \\
\hline 7 & $7.78 \mathrm{~b}_{1}$ & $7.73 \mathrm{a}_{2}$ & $7.24 \mathrm{c}_{3}$ & $7.73 \mathrm{~b}_{4}$ & $7.62 \mathrm{~b}$ \\
\hline 8 & $7.18 \mathrm{c}_{1}$ & $6.71 \mathrm{c}_{2}$ & $6.45 \mathrm{e}_{3}$ & $7.02 \mathrm{c}_{4}$ & $6.86 \mathrm{~d}$ \\
\hline 9 & $7.73 \mathrm{~b}_{1}$ & $7.02 \mathrm{c}_{2}$ & $7.45 \mathrm{c}_{3}$ & $7.29 \mathrm{c}_{4}$ & $7.34 \mathrm{c}$ \\
\hline 10 & $8.01 \mathrm{a}_{1}$ & $8.01 \mathrm{a}_{2}$ & $7.78 \mathrm{~b}_{3}$ & $8.24 \mathrm{a}_{4}$ & $8.01 \mathrm{a}$ \\
\hline 11 & $8.24 \mathrm{a}_{1}$ & $7.51 \mathrm{~b}_{2}$ & $7.73 \mathrm{~b}_{3}$ & $7.51 \mathrm{~b}_{4}$ & $7.73 \mathrm{~b}$ \\
\hline 12 & $8.01 \mathrm{a}_{1}$ & $7.73 \mathrm{a}_{2}$ & $8.24 \mathrm{a}_{3}$ & $8.01 \mathrm{a}_{4}$ & $8.01 \mathrm{a}$ \\
\hline Average & 7.24 & 7.18 & 7.13 & 7.29 & 7.18 \\
\hline Range & $5.86-8.24$ & $6.05-8.01$ & $5.66-8.24$ & $5.86-8.24$ & $6.10-8.01$ \\
\hline LSD 0.05 & 0.31 & 0.31 & 0.31 & 0.31 & 0.16 \\
\hline
\end{tabular}


Table 3. Assessment of the sodding value $(S)$ in relation to the time and place of observation, $a_{1}-f_{3}-$ homogeneous groups

\begin{tabular}{|c|c|c|c|c|c|}
\hline Description & $\begin{array}{c}\text { A1 } \\
(20 \text { IV 2012) }\end{array}$ & $\begin{array}{c}\mathrm{A} 2 \\
(31 \mathrm{~V} 2012)\end{array}$ & $\begin{array}{c}\mathrm{A} 3 \\
(26 \mathrm{VI} 2012)\end{array}$ & $\begin{array}{c}\text { A4 } \\
(22 \times 2012)\end{array}$ & Average \\
\hline 1 & $7.24 \mathrm{c}_{1}$ & $7.29 \mathrm{c}_{2}$ & $7.24 \mathrm{c}_{3}$ & $6.92 \mathrm{~d}_{4}$ & $7.18 \mathrm{~d}$ \\
\hline 2 & $6.05 \mathrm{e}_{1}$ & $6.30 \mathrm{e}_{2}$ & $6.60 \mathrm{e}_{3}$ & $6.05 \mathrm{e}_{4}$ & $6.25 \mathrm{e}$ \\
\hline 3 & $8.24 \mathrm{a}_{1}$ & $8.01 \mathrm{a}_{2}$ & $7.51 \mathrm{c}_{3}$ & $7.78 \mathrm{~b}_{4}$ & $7.90 \mathrm{~b}$ \\
\hline 4 & $7.45 \mathrm{c}_{1}$ & $8.01 \mathrm{a}_{2}$ & $8.01 \mathrm{~b}_{3}$ & $8.01 \mathrm{~b}_{4}$ & $7.84 \mathrm{c}$ \\
\hline 5 & $6.30 \mathrm{e}_{1}$ & $6.25 \mathrm{e}_{2}$ & $5.90 \mathrm{f}_{3}$ & $6.92 \mathrm{~d}_{4}$ & $6.35 \mathrm{e}$ \\
\hline 6 & $6.66 \mathrm{~d}_{1}$ & $7.18 \mathrm{c}_{2}$ & $7.18 \mathrm{~d}_{3}$ & $7.51 \mathrm{c}_{4}$ & $7.13 \mathrm{~d}$ \\
\hline 7 & $8.01 \mathrm{~b}_{1}$ & $7.73 \mathrm{~b}_{2}$ & $7.51 \mathrm{c}_{3}$ & $7.73 \mathrm{~b}_{4}$ & $7.73 \mathrm{c}$ \\
\hline 8 & $7.45 \mathrm{c}_{1}$ & $6.71 \mathrm{~d}_{2}$ & $6.97 \mathrm{~d}_{3}$ & $7.24 \mathrm{c}_{4}$ & $7.08 \mathrm{~d}$ \\
\hline 9 & $8.24 \mathrm{a}_{1}$ & $7.51 \mathrm{~b}_{2}$ & $7.73 \mathrm{~b}_{3}$ & $7.51 \mathrm{c}_{4}$ & $7.73 \mathrm{c}$ \\
\hline 10 & $8.24 \mathrm{a}_{1}$ & $8.24 \mathrm{a}_{2}$ & $8.01 \mathrm{~b}_{3}$ & $8.53 \mathrm{a}_{4}$ & $8.24 \mathrm{a}$ \\
\hline 11 & $8.53 \mathrm{a}_{1}$ & $7.78 \mathrm{~b}_{2}$ & $8.01 \mathrm{~b}_{3}$ & $7.78 \mathrm{~b}_{4}$ & $8.01 \mathrm{~b}$ \\
\hline 12 & $8.24 \mathrm{a}_{1}$ & $8.01 \mathrm{a}_{2}$ & $8.53 \mathrm{a}_{3}$ & $8.24 \mathrm{a}_{4}$ & $8.24 \mathrm{a}$ \\
\hline
\end{tabular}

while in analysis No. 2 (A2) the smallest variation was noted in the sodding of the pitch turfgrass. The observations carried out in spring (A1) and autumn (A4) indicate repeated, similar sodding during these periods.

The study confirmed also a dependence of the results and analysed half of the pitch, where the left (northern) part of the sports turfgrass had much higher results in comparison with the right (southern) half. Over the entire study period the left side of the field was characterised by better sodding, due to better light conditions over the year (Fig. 3). It can be concluded that the overall sodding on the pitch at the City Stadium is satisfactory, especially during periods of intensive exploitation of the turf. This indicates knowledge of the rules of pratotechnics and of its application by persons responsible for the turfgrass surface care.

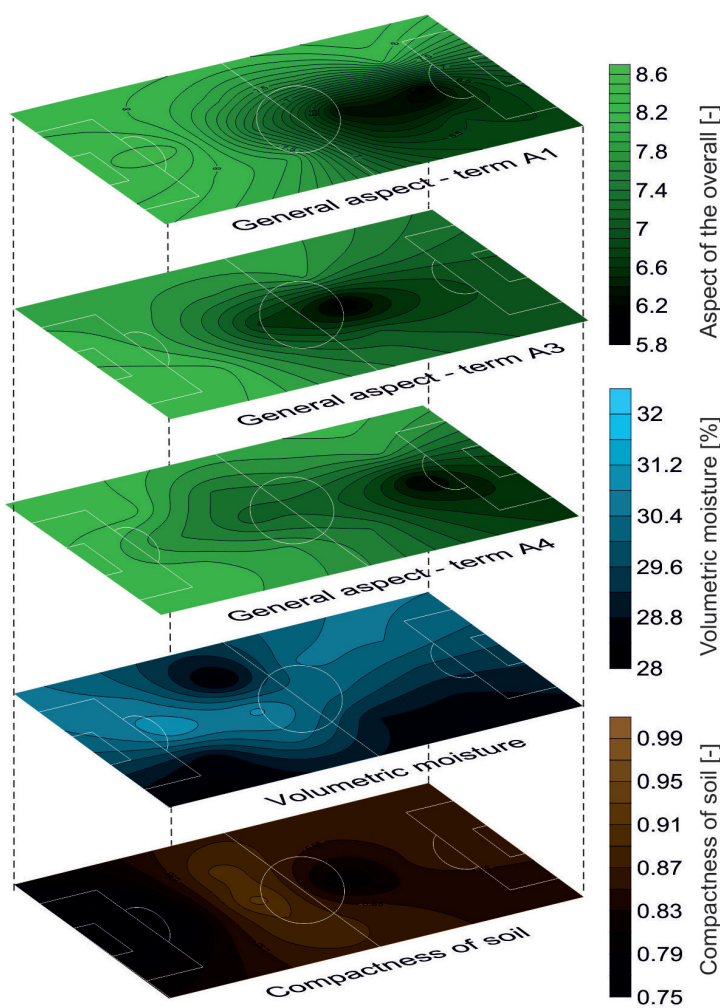

Fig. 2. Assessment of the general aspect value (Ao), volumetric moisture and compactness of soil in relation to the time and place of observation.

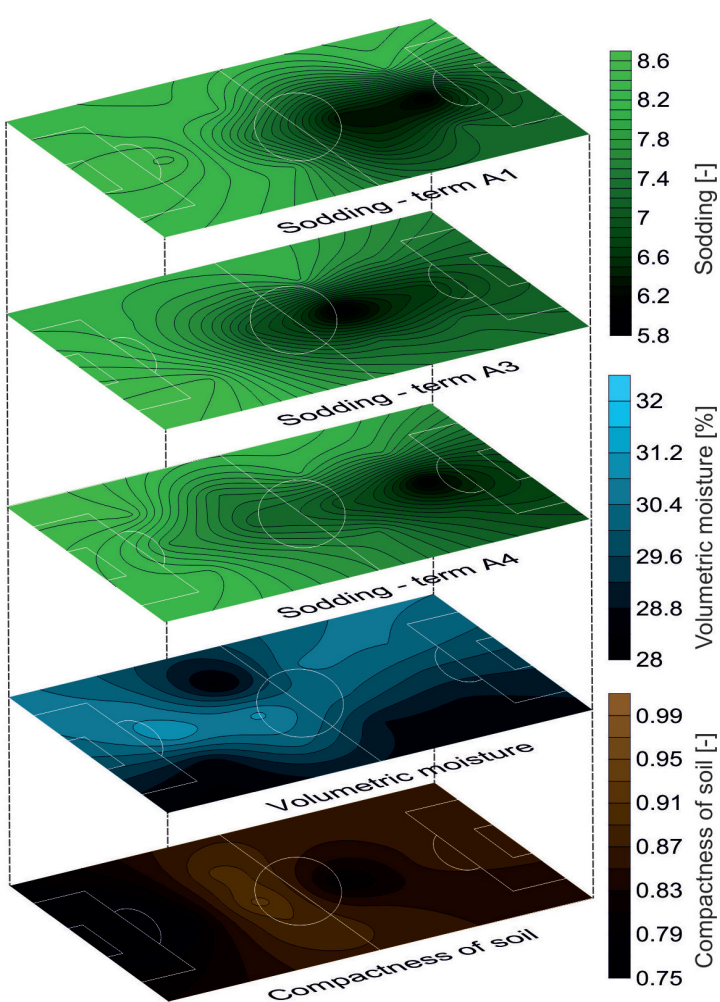

Fig. 3. Assessment of the sodding value (S), volumetric moisture and compactness of soil in relation to the time and place of observation. 


\section{Assessment of colour value}

In assessing the colour value (C) in 2012, on four dates of analysis (spring, summer, autumn), it was noted that the diversity of the turf in the context of colour was slight (Table 4).

In all the analyses conducted in the scope of the study, the difference between the highest and the lowest value did not exceed 1.0, and in bonitation analysis that does not result in any significant change in the colour of the grass. The colour of brass leaves was between brownish green and emerald which is the most representative and desirable turf colour.

The lowest colour value of the turfgrass was recorded in playing field, on the right side of the pitch, at points $2,5,8$. During the whole year, the turfgrass colour in point 2 was characterised by constant and the lowest colour value. Over the entire study period, turfgrass in points 10-12 was characterised by the highest and constant colour value (Fig. 4).

This shows correct substrate preparation and optimal sports turfgrass care. The study allows to conclude that for the entire football pitch this aspect is important and the pitch turf at the City Stadium in Wroclaw was considered to be of uniform colour.

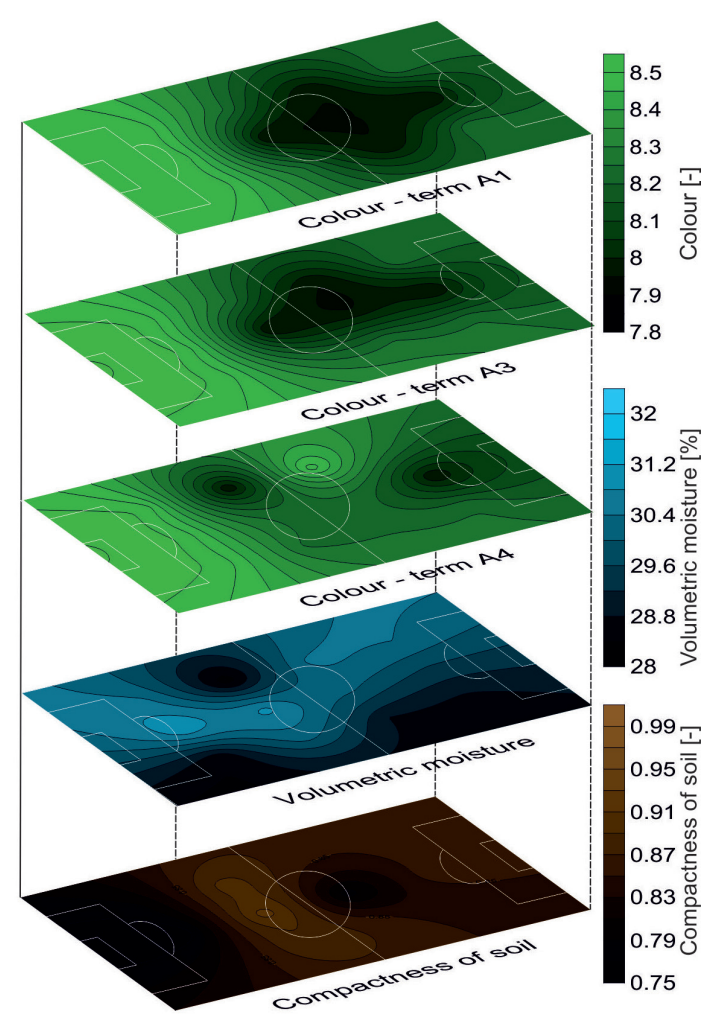

Fig. 4. Assessment of the colour value (C), volumetric moisture and compactness of soil in relation to the time and place of observation.

\section{Assessment of winter survival value}

In assessing the winter survival value (W) in the spring of 2013 (A5) differences were found in the substrate coverage with living plants. The range of values was in the range of 6.70-9.00 (Table 5).

The lowest score was observed, in the earlier analyses, on the grass on right half of the pitch, which indicated medium to good level of the turf. Grass in the middle of the pitch was characterised by equally bad overwintering. At low moisture areas of the pitch, turfgrass winter survival was at the highest level. In places where the substrate showed the highest moisture level, turfgrass overwintered worse (Fig. 5). Similarly, higher value and better appearance of turf was observed on the northern part of the pitch, but in this case the highest score was not achieved. Very good sodding also found on the southern side, characterised by an absence of loss of plants. However, this does not exclude the dependence confirmed in the earlier analyses, that the southern playing field is much more diversified and used, therefore, it requires more intensive care that will allow to achieve as good results as those in the northern part.

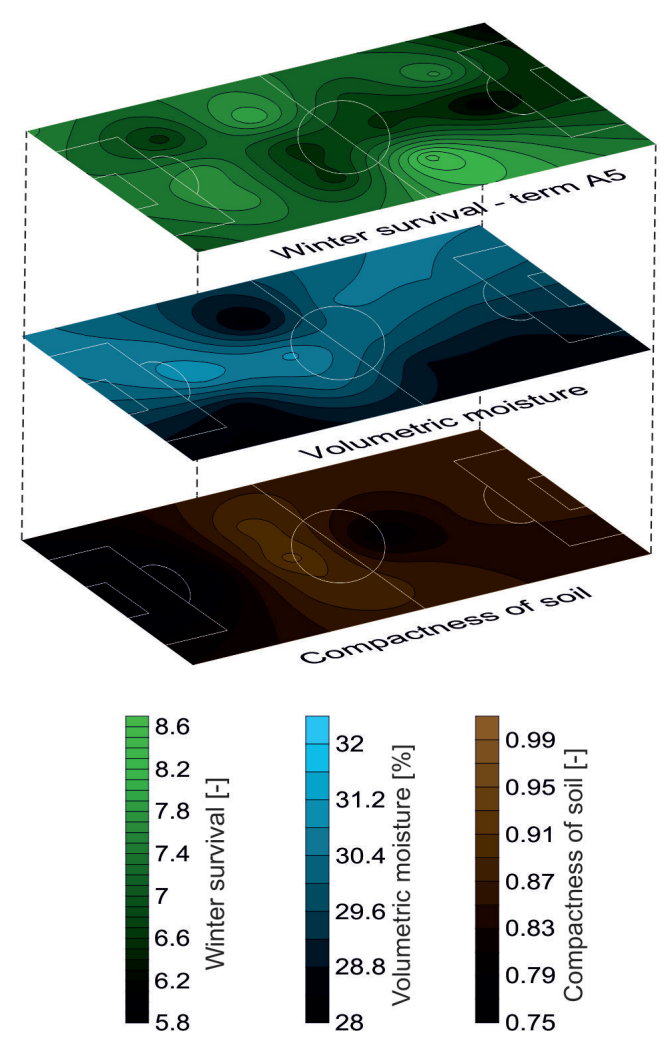

Fig. 5. Assessment of the winter survival value (W), volumetric moisture and compactness of soil in relation to the time and place of observation. 
Table 4. Assessment of the colour value (C) in relation to the time and place of observation, a1-e - homogeneous groups.

\begin{tabular}{|c|c|c|c|c|c|}
\hline Description & $\begin{array}{c}\mathrm{A} 1 \\
(20 \text { IV 2012) }\end{array}$ & $\begin{array}{c}\mathrm{A} 2 \\
(31 \mathrm{~V} 2012)\end{array}$ & $\begin{array}{c}\mathrm{A} 3 \\
(26 \mathrm{VI} 2012)\end{array}$ & $\begin{array}{c}\text { A4 } \\
(22 \times 2012)\end{array}$ & Average \\
\hline 1 & $8.24 \mathrm{~b}_{1}$ & $8.24 \mathrm{~b}_{2}$ & $8.24 \mathrm{~b}_{3}$ & $8.24 \mathrm{~b}_{4}$ & $8.24 \mathrm{~b}$ \\
\hline 2 & $7.95 \mathrm{c}_{1}$ & $7.95 \mathrm{c}_{2}$ & $7.95 \mathrm{c}_{3}$ & $7.95 \mathrm{c}_{4}$ & $7.95 \mathrm{e}$ \\
\hline 3 & $8.24 \mathrm{~b}_{1}$ & $8.24 \mathrm{~b}_{2}$ & $8.24 \mathrm{~b}_{3}$ & $8.24 \mathrm{~b}_{4}$ & $8.24 \mathrm{~b}$ \\
\hline 4 & $7.95 \mathrm{c}_{1}$ & $8.24 \mathrm{~b}_{2}$ & $7.95 \mathrm{c}_{3}$ & $8.53 \mathrm{a}_{4}$ & $8.18 \mathrm{c}$ \\
\hline 5 & $7.95 \mathrm{c}_{1}$ & $7.95 \mathrm{c}_{2}$ & $7.95 \mathrm{c}_{3}$ & $8.24 \mathrm{~b}_{4}$ & $8.01 \mathrm{~d}$ \\
\hline 6 & $7.95 \mathrm{c}_{1}$ & $8.24 \mathrm{~b}_{2}$ & $8.24 \mathrm{~b}_{3}$ & $8.24 \mathrm{~b}_{4}$ & $8.18 \mathrm{c}$ \\
\hline 7 & $8.24 \mathrm{~b}_{1}$ & $8.24 \mathrm{~b}_{2}$ & $8.24 \mathrm{~b}_{3}$ & $8.24 \mathrm{~b}_{4}$ & $8.24 \mathrm{~b}$ \\
\hline 8 & $7.95 \mathrm{c}_{1}$ & $7.95 \mathrm{c}_{2}$ & $7.95 \mathrm{c}_{3}$ & $8.24 \mathrm{~b}_{4}$ & $8.01 \mathrm{~d}$ \\
\hline 9 & $8.24 \mathrm{~b}_{1}$ & $8.24 \mathrm{~b}_{2}$ & $8.24 \mathrm{~b}_{3}$ & $7.95 \mathrm{c}_{4}$ & $8.18 \mathrm{c}$ \\
\hline 10 & $8.53 \mathrm{a}_{1}$ & $8.53 \mathrm{a}_{2}$ & $8.53 \mathrm{a}_{3}$ & $8.53 \mathrm{a}_{4}$ & $8.53 \mathrm{a}$ \\
\hline 11 & $8.53 \mathrm{a}_{1}$ & $8.53 \mathrm{a}_{2}$ & $8.53 \mathrm{a}_{3}$ & $8.53 \mathrm{a}_{4}$ & $8.53 \mathrm{a}$ \\
\hline 12 & $8.53 \mathrm{a}_{1}$ & $8.53 \mathrm{a}_{2}$ & $8.53 \mathrm{a}_{3}$ & $8.53 \mathrm{a}_{4}$ & $8.53 \mathrm{a}$ \\
\hline Average & 8.18 & 8.24 & 8.18 & 8.29 & 8.24 \\
\hline Range & $7.95-8.53$ & $7.95-8.53$ & $7.95-8.53$ & $7.95-8.53$ & $7.95-8.53$ \\
\hline LSD 0.05 & 0.10 & 0.10 & 0.10 & 0.10 & 0.05 \\
\hline
\end{tabular}

Table 5. Assessment of the winter survival value (W) in relation to place of observation, a1-f1 - homogeneous groups.

\begin{tabular}{|c|c|}
\hline Description & $\begin{array}{c}\text { A5 } \\
(26 \text { IV 2013) }\end{array}$ \\
\hline 1 & $7.95 \mathrm{~d}_{1}$ \\
\hline 2 & $6.70 \mathrm{~g}_{1}$ \\
\hline 3 & $8.18 \mathrm{c}_{1}$ \\
\hline 4 & $7.45 \mathrm{e}_{1}$ \\
\hline 5 & $7.24 \mathrm{f}_{1}$ \\
\hline 6 & $9.00 \mathrm{a}_{1}$ \\
\hline 7 & $7.18 \mathrm{f}_{1}$ \\
\hline 8 & $7.18 \mathrm{f}_{1}$ \\
\hline 9 & $8.53 \mathrm{~b}_{1}$ \\
\hline 10 & $7.18 \mathrm{f}_{1}$ \\
\hline 11 & $8.24 \mathrm{c}_{1}$ \\
\hline 12 & $8.24 \mathrm{c}_{1}$ \\
\hline Average & 7.78 \\
\hline Range & $6.70-9.00$ \\
\hline LSD 0.05 & 0.32 \\
\hline
\end{tabular}

\section{DISCUSSION}

Sports turfgrass surfaces are created mainly of lawn grasses, the visual and functional quality of which influence heavily the results and the viewing quality of football games [Chivers 2008, Huff 2010, Wolski 2002]. They are characterised by turf that is short, compact and durable under intensive use [Ekstrand et al. 2006, Grabowski et al. 2006, Harivandi et al. 2008]. The selection of appropriate species and varieties of grasses, combined with correct substrate preparation and care treatments, can determine the quality of turf [Ekstrand et al. 2006, Grabowski et al. 2006, Harivandi et al. 2008].

The best traction parameters are characteristic of earth-and-sand substrates that guarantee the required hardness and permeability while retaining high quality of turf. Exceeding the recommended norms leads to notable deterioration of visual (non-uniform sodding) and functional (substrate compaction) parameters and to reduced possibility of turf regeneration [Follis et al. 2008].

The general aspect value (Ao) determines the compositional value of varieties resulting from interaction of the genotype and environmental factors [Domański 1992, Sampoux et al. 2012]. Studies by Radkowski and Styrc [2006] show that under medium intensive use of Lolium perenne L. the highest value is obtained during the summer, then autumn, and the lowest in spring. Similar results were obtained by Domański [1998] who showed that under intensive use of turf from seed of varieties of perennial ryegrass, the highest visual effect is observed in summer. According to Brede [2008] and Martyniak [2003a], general aspect is one of the features determining the grassseed value of lawn varieties of Poa pratensis L. Studies on the varieties bred by IHAR, and on registered national and international varieties, show that the utility value of Kentucky bluegrass varies according to the season of the year. The highest scores were obtained in the summer, 
while the lowest in the spring season, and the results of the new varieties were less divergent [Martyniak 2003b]. Similar results were observed during the analyses of general aspect on the selected dates during the growing season at the City Stadium in Wroclaw.

The next analysed feature was sodding (S), i.e. the seasonal cover of the substrate with grass leaf blades; the higher the degree of the coverage, the higher the evaluation score [Radkowski and Styrc 2006]. Many researchers demonstrated that the density of the turf is significantly affected by the repent root system and vegetative plant propagation, and sodding itself is dependent on the height and frequency of mowing [Radkowski and Styrc 2006, Turgeon 2008]. Harkot and Czarnecki argue that sodding is affected by factors such as quick and even plant emergence and care treatments. The selection of grass species and varieties, and their percentage share, have an impact on the degree of substrate cover by grass leaves [Harkot and Czarnecki 1999]. The diversity and the degree of sodding will vary depending on the time of year, but a majority share of perennial ryegrass and Kentucky bluegrass, compared to other species of grass, provide higher performance of sodding throughout the growing season [Grabowski et al. 2006, Grabowski et al. 2003].

Grass colour (C) grass is a useful indicator of the overall condition the plants and is defined as the measure of the light reflected by the turf. Depending on the variety and species, colour from light to dark green is observed [Turgeon 2010]. During plant vegetation, colour stability and susceptibility to change under stress is an overriding feature, according to Prończuk [1993]. The results presented by Grabowski et al. [2006] and the analyses of the turf at the City Stadium show that the most representative was the turf during the full growing season, and less so in the autumn. Because of that, it was concluded that the colour of the turf is dependent on the time of year, and to a lesser degree on the mixture of grasses [Grabowski et al. 2006].

In Polish climatic conditions, winter survival is important because it is the result of interactions of snow cover, cold temperatures and pathogens, and their combined effect on the grass. It is also the basis in the characterisation of varieties and, combined with the overall aspect, winter hardiness and quality index, it is a very important utility feature. In studies on the varieties of $\mathrm{Poa}$ pratensis $\mathrm{L}$. a diversity was observed in the lawn characteristics, that was the most pronounced in the assessment of winter survival, winter hardiness and resistance to infection [Brede 2008, Prończuk 1993, Prończuk and Prończuk 2003].

The presence of pathogens and infections reduce the visual and functional aspects of sports turfgrass. In the case heated turf, attention shout be paid to the temperature during the winter. Increasing the temperature above $5^{\circ} \mathrm{C}$, and thus overheating grass roots, has a negative impact on the condition of the turf [Pląskowska and Wolski 2011]. Whereas, in the summer the greatest threat to lawn grasses are fungal pathogens of the genera Fusarium and Rhizoctonia [Pląskowska et al. 2006b]. Research carried out in 1996- 1998 on the health status of turf under intensive use in Lower Silesia showed that grass species differ in susceptibility to diseases, but among the lawn grasses the greatest threat is that of snow mould [Pląskowska et al. 2006a]. However, many scientists agree in the claim that intensively use of turfgrass and adequate knowledge of pratotechnics can help prevent the spreading of pathogens and infections [Bruce et al. 2008]. At the City Stadium in Wroclaw, both aspects were taken into account, which largely resulted in non-appearance of pathogens and in winter survival of most of the grasses in good condition.

\section{CONCLUSIONS}

1. Under the climatic conditions of Lower Silesia, the best solution is the use of a mixture of grasses composed of $50 \%$ of Lolium perenne L. and $50 \%$ of Poa pratensis L., which was taken into account in the establishment of the turf at the City Stadium in Wroclaw.

2. Even proportions of perennial ryegrass and Kentucky bluegrass in the mixture of grasses contributes to the achievement of very good overall aspect, colour and sodding of the football turf.

3. The use pratotechnics during the growing season of grasses, especially during intensive exploitation of sports turfgrass, improves the utility value and especially the sodding of the turf.

4. Intensive use and care treatments of plants prevent the spread of pathogens that cause serious diseases of turfgrasses.

5. Adequate turf lighting conditions determine a proper development of grasses and their desirable colour, which contributes to high rating of 
the overall aspect of football pitch turf. Even distribution of light on the pitch contributes to the achievement of uniform colour of the grass.

6. The final conclusion is that the turf at the City Stadium is a good example supporting the validity of the claim of many scientists that the selection of grass mixture suitable to the climatic conditions and to the intended usage, and applied care treatments, strongly affect the quality of turfgrasses.

\section{REFERENCES}

1. Brede D. 2008. Multi-Way Kentucky bluegrass blends and their effect on Turfgrass Quality. Acta Hortic., 783, 19-27. doi: 10.17660/ActaHortic.2008.783.1.

2. Bruce B.C., Majumdar P.R., Peacos M., Chung Yew J.P., Burnett A., Gunasekera S., Fitzgerald D., Lawson T.J., Roberts J., Clarke K.E., Pitonak A., Dickson W.K., Clark J.B., Inguagito J. 2008. Preventive control of anthracnose with selected fungicides and biorational products on an annual bluegrass putting green. Rutgers Turfgrass Proceedings. New Jersey Turfgrass Associaction, 249-263.

3. Chivers I. 2008. Turfgrass sports surfaces and their relationship to player injuries. Acta Hort.,783, 115-132.

4. Deutsche Norm - DIN 18035 cz. 4. Sportplätze. Rasenflächen, Teil 4, 1991.

5. Domański P. 1992. The research and evaluation of varieties of turfgrass in Poland. Bulletin of the Institute of Plant Breeding and Acclimatization, 183, 252-263.

6. Domański P. 1998. Methods of study of the economic value of crop varieties. Turfgrasses: red fescue, timothy grass, Kentucky bluegrass, perennial ryegrass. COBORU Edition I. Slupia Wielka, 1-35.

7. Drozd J., Licznar M., Licznar St., Weber J. 2002. Soil science with elements of mineralogy and petrography (in Polish). Wydawnictwo AR Wrocław.

8. Ekstrand J., Timpka T., Hagglund M. 2006. Risk of injury in elite football played on artificial turf versus natural grass: a prospective two-cohort study. Br J. Sports Med., 40(12), 975-980. doi: 10.1136/ bjsm.2006.027623.

9. European Commission. Common Catalogue of Varieties of Agricultural Plant 31. complete edition (2012/ C 402 A/01. Messages Institutions, Bodies and Organs of the European Union, pp: 97, 99, 115, 123, 125, 2012.

10. Follis C.C., Anderson S.H., Fresenburg B.S., Ervin E.H. 2008. Evaluation of sand-soil-compost root zones developed for athletic fields. Acta Hort., 783, 97-104. Record Number: 20083241038.

11. Grabowski K., Grzegorczyk S., Benedycki S., Kwietniewski H. 2003. Excellent usability of lawn of Lolium perenne (in Polish). Grassland in Poland, 6, 69-77.

12. Grabowski K., Grzegorczyk S., Kwietniewski H. 2006. Usefulness of 10 mixtures of grasses to sow the sports pitch (in Polish). Scientific Journal of Wroclaw University of Environmental and Life Sciences, Series of Agronomy LXXXVIII, 545, 95-102.

13. Harivandi, M.A., Hagan, W.B., Morris, K.N. 2008. Evaluating bentgrasses for quality, ball-roll distance, thatch/mat development and annual bluegrass invasion. Acta Horticulturae. 783, 309-316. doi: 10.17660/ActaHortic.2008.783.32.

14. Harkot W., Czarnecki Z. 1999. Usefulness of Polish varieties of lawn grasses to sodding of surface in difficult soil conditions (in Polish). Folia Univ. Agric. Stetin 197, Agriculture 75, 117-120.

15. Huff D.R. 2010. Bluegrasses [In:] Fodder Crops and Amenity Grasses, B. Boller, U.K. Posselt, F. Veronesi (eds.), Handbook of Plant Breeding 5, Springer Publishing, 345-379. Doi: 10.1007/9781-4419-0760-8_15.

16. Loch D. 2013. Zoysias: the environmental turfgrass. Australian Turfgrass Management Journal 15(1), 46-49.

17. Macolino S., Lucon M., Scotton M., Altissimo A., Ziliotto U. 2004a. Effect of Simulated Traffic on Some Turf Quality Parameters in Construction Systems of Soccer Pitches. ActaHortic. 661, 5357. doi: 10.17660/ActaHortic.2004.661.4.

18. Macolino S., Scotton M., Lucon M., Ziliotto U. 2004b. Effect of Simulated Traffic on Vegetative Evolution of Turfgrass in Construction Systems of Soccer Pitches. Acta Hortic. 661, 375-379. doi: 10.17660/ActaHortic.2004.661.51.

19. Martyniak D. 2003a. Lawn value of new Poa pratensis L. cultivars bred at IHAR (in Polish). Biul. IHAR, 225, 32-328.

20. Martyniak D. 2003b. Biological traits determining turf performance and seed value of Kentucky bluegrass (Poa pratensis L.) - literature review (in Polish). Biul. IHAR, 228, 335-344.

21. Mynett M., Prończuk M. Prończuk S. 2010. A beautiful lawn (in Polish). Multico Printing House. Warsaw, Sygn.: 251969; D.654 Ogr.

22. Pląskowska E., Wolski K. 2011. Health research of the heated football turfs (in Polish). Advances of Agricultural Sciences Problem Issues, 562, 187-195.

23. Pląskowska E., Wolski K., Moszczyńska E., Kaczmarek J. 2006a. Study of the healthiness of spe- 
cies and cultivars of turfgrass and their mixtures for football pitches (in Polish). Scientific Journal of Wroclaw University of Environmental and Life Sciences, Series of Agronomy LXXXVIII, 545, 211-219.

24. Pląskowska E., Wolski K., Moszczyńska E., Zacharkiewicz- Witan K. 2006b. Grass healthiness evaluation on football pitches under intensive turf wear (in Polish). Scientific Journal of Wroclaw University of Environmental and Life Sciences, Series of Agronomy LXXXVIII, 545, 221-227.

25. Prończuk S. 1993. System of evaluation of lawn grasses (in Polish). Biul. IHAR 225, 239-257.

26. Prończuk S., Prończuk M. 2003. Variability of turf characters of Poa pratensis L. cultivars under medium intensive turf maintenance (in Polish). Biul. IHAR, 225, 265-276.

27. Radkowski A., Styrc N. 2006. Estimation of perennial ryegrass value in amenity cultivation under two methods of exploitation (in Polish). Scientific Journal of Wroclaw University of Environmental and Life Sciences, Series of Agronomy LXXXVIII, 545, 255-260.

28. Regulation of the Minister of the Environment of $9^{\text {th }}$ September 2002 on standards of soil quality and on standards of earth quality (in Polish) (Dz.U. 2002 No. 165 item 1359).

29. Sampoux J.P., Baudouin P., Bayle B., Bèguier V.,
Bourdon P., Chosson J.F., de Bruijn K., Deneufbourg F., Galbrun C., Ghesquière M., Noël D., Tharel B., Viguiè A. 2012. Breeding perennial ryegrass (Lolium perenne L.) for turf usage: an assessment of genetic improvements in cultivars released in Europe. 1974-2004. Grass and Forage Science, 68, 33-48. DOI: 10.1111/j.13652494.2012.00896.x.

30. Skirde W. 2008. Bemerkungen zur Entwicklug von DIN 18035-4: Sportplätze-Rasenflächen, Neue Landschaft, 7/08, 41-47.

31. Turgeon A. J. 2008. Turfgrass Management, 8th Edition. Pearson Prentice Hall, Upper Saddle River, New Jersey, 436 pages.

32. Wolski K. 2002. Analysis of selected elements of football played on sward before and after renovation (in Polish). Scientific Review Engineering and Environmental Sciences, 1(24), 210-213.

33. Wolski K., Gawęcki J., Bartmański A., Sokulska D., Baranowski M. 2006, Suitability of turfgrass species, varieties and mixtures for turfing football grounds (in Polish). Scientific Journal of Wroclaw University of Environmental and Life Sciences, Series of Agronomy LXXXVIII, 545, 285-291.

34. Wysocki C. 2002. Natural and technical conditions in designing elaborations sports lawn (in Polish). Review Engineering and Environmental. Publisher SGGW. Warsaw, 34-42. 